\title{
PENGARUH BERAT POTONG DAN HARGA PEMBELIAN DOMBA DAN KAMBING BETINA TERHADAP GROSS MARGIN JAGAL DI RUMAH POTONG HEWAN MENTIK, KRESEN, BANTUL
}

\author{
THE EFFECT OF SLAUGHTER WEIGHT AND PURCHASE PRICE OF FEMALE SHEEP \\ AND GOATS ON THE BUTCHER'S GROSS MARGIN AT MENTIK SLAUGHTER HOUSE, KRESEN, \\ BANTUL
}

\author{
Wisnu Widiarto*, Rini Widiati, dan I Gede Suparta Budisatria \\ Fakultas Peternakan, Universitas Gadjah Mada, Jl. Fauna No.3, Bulaksumur, Yogyakarta, 55281
}

\section{INTISARI}

Penelitian ini bertujuan untuk mengetahui pengaruh berat potong dan harga pembelian domba dan kambing terhadap gross margin jagal di RPH Mentik Kresen Bantul. Penelitian dilaksanakan dengan obyek penelitian aktivitas produksi jagal domba dan kambing lokal betina. Sampel yang digunakan adalah ternak domba dan kambing betina lokal masing-masing 60 ekor. Sampel dibagi masing-masing 30 ekor dalam berat potong 10 sampai14,99 $\mathrm{kg}\left(\mathrm{BP}_{1}\right)$ dan berat potong 15 sampai $20 \mathrm{~kg}\left(\mathrm{BP}_{2}\right)$. Data yang diambil adalah harga beli, berat potong, biaya variabel, produksi karkasnonkarkas dan gross margin jagal. Uji faktorial digunakan untuk mengetahui perbedaan antara jenis ternak dan kelompok berat hidup mana yang paling baik untuk produksi per ekor domba dan kambing. Analisis regresi linier berganda untuk mengetahui pengaruh harga beli dan berat potong terhadap produksi domba dan kambing, serta berat potong dan biaya variabel terhadap gross margin jagal domba dan kambing. Hasil penelitian menunjukkan kambing Bligon betina dengan berat potong 15-20 kg menghasilkan produksi dan gross margin yang paling tinggi yaitu sebesar 9,83 kg dan Rp. 104.901,50. Harga beli dan berat potong secara signifikan dan positif berpengaruh terhadap produksi domba dan kambing lokal betina dengan $\mathrm{R}^{2}=0,718$. Terdapat perbedaan produksi pada domba dan kambing. Produksi kambing lebih baik dari produksi domba. Berat potong secara signifikan dan positif berpengaruh terhadap gross margin jagal. Biaya variabel secara signifikan dan negatif berpengaruh terhadap gross margin jagal dengan $\mathrm{R}^{2}=0,665$. Semakin tinggi biaya variabel akan menurunkan gross margin jagal. Terdapat perbedaan gross margin domba dan kambing. Gross margin kambing lebih baik dari gross margin domba. Berdasarkan hasil penelitian dapat disimpulkan bahwa produksi dan gross margin kambing betina lebih baik dari domba betina.

(Kata kunci: Domba dan kambing lokal betina, Persentase karkas dan nonkarkas, Produksi, Gross margin)

\section{ABSTRACT}

This study was aimed to determine the effect of slaughter weight and purchasing price of female sheep and goats on the butcher's gross margins at the slaughterhouse of Mentik, Kresen, Bantul. The study was conducted to determine the production activities of butchers. Sixty heads of local female sheep and goats respectively, were used as samples. The animals were divided into two groups, based on its body weight, namely 10 to $14.99 \mathrm{~kg}\left(B P_{I}\right)$ and 15 to $20 \mathrm{~kg}$ $\left(\mathrm{BP}_{2}\right)$ of body weight. The data consisted of purchasing price, slaughter weight, variable cost, dressing and non carcass percentages and the butcher's gross margin. Factorial analysis was used to determine the ratio between spesies and groups which live weight is best for the production of sheep and female goats. Multiple linear regression analysis was used to determine the effect of slaughter weight and purchase price to production of female sheep and goats, and slaughter weight and variable costs to gross margin of sheep and female goats butchers. The results showed that Bligon female goats of 15-20 kg body weight has the highest value on production and gross margins, it was $9.83 \mathrm{~kg}$ and $\mathrm{Rp}$. 104,901.50, respectively. The purchasing price and the slaughter weight significantly and positively affecting the production of female local sheep and goats with $R^{2}=0.718$, female goats has better production than sheep. Slaughter weight significantly and positively affecting the gross margin of the butcher. Variable costs significantly and negatively affecting the gross margins of the butcher with $R^{2}=0.665$. Higher variable cost will reduce the butcher's gross margin. There were differences in the gross margin of female sheep and goat. The Gross margin of female goats was better than the gross margins of sheep. It can be concluded that local female goat's production and gross margin was better than sheep.

(Key words: Female local sheep and goats, Dressing and non carcass percentages, Production and Gross margin)

\footnotetext{
* Korespondensi (corresponding author):

Telp. +62 8562877028

E-mail: wisnu_roro@yahoo.com
} 


\section{Pendahuluan}

\section{Latar belakang}

Domba dan kambing merupakan salah satu komoditas ternak penghasil daging yang potensial, dikarenakan perkembangannya relatif cepat dibanding ternak ruminansia besar. Domba dan kambing bisa beranak 3 kali dalam 2 tahun dan setiap beranak 2 atau 3 ekor. Hampir semua ternak tersebut dipelihara oleh masyarakat pedesaan sehingga disamping sebagai sumber pemenuhan pangan protein hewani, beternak domba dan kambing sekaligus dapat memperluas lapangan pekerjaan, meningkatkan pendapatan dan mendukung ketahanan pangan bagi masyarakat pedesaan. Lapangan pekerjaan tidak hanya pada sub sektor budidaya, tetapi juga melibatkan sub sektor pengadaan sarana produksi dan pasca panen serta pemasaran yang sangat lekat kaitanya dengan jagal.

Konsumsi daging di Indonesia sampai dengan saat ini masih rendah yaitu 2,49 gram/kapita/hari, disuplai daging unggas $56 \%$, daging sapi $23 \%$, daging babi $13 \%, 5 \%$ daging domba dan kambing dan lainnya 3\% (Djajanegara dan Misniwaty, 2007). Berdasarkan perhitungan konsumsi daging domba dan kambing masyarakat Indonesia masih rendah 0,24 gram/kapita/hari bila dibandingkan Jerman 3,33 gram/kapita/th, Rusia 3,36 gram/kapita/th, Cina 6,39 gram/kapita/th, Perancis 13,89 gram/ kapita/th, Inggris 16,94 gram/kapita/th, Yunani 38,61 gram/kapita/th, Australia 52,50 gram/ kapita/th dan yang tertinggi adalah New Zealand yaitu 81,11 gram/kapita/th (Anonimus, 2000).

Meningkatkan produksi dan produktivitas domba dan kambing akan memberikan peluang usaha bagi peternak, industri penyedia sarana produksi dan pelaku pemasaran terutama jagal, namun demikian, peningkatan produksi dan produktivitas harus disertai dengan pemerataan pendapatan diantara para pelaku tersebut. Pada penelitian ini difokuskan pada aktivitas pemasaran domba dan kambing yang dilakukan oleh jagal. Jagal mempunyai dua fungsi, yaitu dari sisi peternak, jagal merupakan konsumen ternak hidup sedangkan dari sisi konsumen daging domba dan kambing, jagal merupakan produsen sehingga dapat dikatakan jagal mempunyai posisi sentral yang dapat menentukan harga pembelian domba dan kambing dari peternak dan menentukan harga jual daging domba dan kambing kepada konsumen, dengan asumsi jumlah peternak banyak dibanding jumlah jagal hanya beberapa orang.

Dalam pemasaran produk domba dan kambing di Indonesia, jagal melakukan fungsi perubahan bentuk dari ternak hidup menjadi daging dan komponennya. Tujuan pemotongan ternak adalah untuk memperoleh karkas serta daging sebagai produk yang akan menentukan pendapatan jagal. Secara umum hasil pemotongan dapat dibagi menjadi dua bagian yaitu karkas dan nonkarkas. Karkas merupakan hasil pemotongan ternak yang mempunyai nilai ekonomi yang tinggi. Di negaranegara maju, nonkarkas kurang memiliki nilai ekonomis namun di Indonesia hasil permotongan ternak yang berupa nonkarkas masih mempunyai nilai ekonomis yang cukup tinggi.

Jagal seperti halnya pelaku ekonomi pada umumnya memiliki prinsip ekonomi untuk mendapatkan keuntungan, sehingga harus memperhatikan biaya produksi berupa harga pembelian ternak di pasar. Penilaian harga seekor domba dan kambing umumnya didasarkan pada berat hidupnya, tetapi pada kenyataannya berat badan ternak hanya berdasarkan perkiraan jagal. Besarnya berat hidup akan menentukan berat karkas dan berat bagianbagian tubuh yang lain. Untuk mendapatkan informasi data yang dapat dijadikan sebagai referensi bagi berbagai pihak yang terkait, maka peneliti tertarik untuk melakukan penelitian tentang pengaruh berat potong domba dan kambing serta harganya terhadap pendapatan jagal dan apakah ada perbedaan antara domba dan kambing.

\section{Materi dan Metode}

\section{Materi}

Penelitian dilaksanakan di rumah potong hewan (RPH) Kresen, Kecamatan Bantul, Yogyakarta. Materi yang digunakan dalam penelitian ini adalah domba dan kambing lokal betina masing-masing 30 ekor dengan kisaran berat potong 10 sampai $14,99 \mathrm{~kg}\left(\mathrm{BP}_{1}\right)$ dan berat potong 15 sampai $20 \mathrm{~kg}\left(\mathrm{BP}_{2}\right)$.

\section{Metode}

Metode penelitian ini merupakan penelitian survei yang dilaksanakan di RPH Kersen. Pengambilan data dengan cara pengukuran variabel berat potong, karkas dan nonkarkas dilakukan pada saat pemotongan domba dan kambing pada pukul 04.00 WIB sampai 07.30 WIB.

Dalam mengukur variabel-variabel berat potong, berat karkas dan nonkarkas digunakan alat timbangan merk Shinano ${ }^{\circledR}$ dengan kapasitas $6 \mathrm{~kg}$ untuk menimbang karkas, kulit, kaki, kepala, jantung, hati, paru-paru dan saluran pencernaan dengan kepekaan 0,1 gram; timbangan ternak merk Berkell@ dengan kapasitas $50 \mathrm{~kg}$ untuk menimbang berat potong ternak domba dan kambing sebelum dipotong dengan kepekaan $0,5 \mathrm{~kg}$; pisau dan tali. 


\section{Pengambilan sampel}

Sampel yang diambil adalah ternak domba dan kambing lokal betina masing-masing 60 ekor secara purposive. Domba dan kambing dibedakan masing-masing 30 ekor dalam berat potong 10 sampai $14,99 \mathrm{~kg}\left(\mathrm{BP}_{1}\right)$ dan berat potong 15 sampai $20 \mathrm{~kg}\left(\mathrm{BP}_{2}\right)$.

\section{Pengambilan data sebelum disembelih}

Sebelum disembelih, domba dan kambing lokal betina yang terpilih sebagai sampel diamati umur potong dengan melihat pergantian gigi seri. Apabila gigi seri susu belum berganti, maka ternak dimasukkan pada kelompok umur kurang dari satu tahun. Apabila gigi seri susu pertama sudah berganti menjadi gigi seri tetap, maka ternak dimasukkan pada kelompok umur 1-2 tahun. Apabila gigi seri susu kedua telah berganti menjadi gigi seri tetap, maka ternak dimasukkan pada kelompok umur 2-3 tahun. Selanjutnya dilihat kondisi tubuhnya. Domba dan kambing lokal ditimbang untuk diketahui berat potongnya.

\section{Pemotongan}

Pemuasaan. Sebelum dilakukan pemotongan ternak dipuasakan selama 12 jam untuk mendapatkan berat hidup kosong.

Cara penyembelihan. 1) Penyembelihan dilakukan secara Islam; 2) Pengeluaran darah sebanyak-banyaknya; 3) Pemisahan kepala dari tubuhnya setelah ternak benar-benar mati; dan 4) Penyiapan karkas termasuk pengulitan.

Cara menguliti. Setelah penyembelihan dan ternak benar-benar mati, maka dilakukan pengulitan. Cara pengulitan yang dilakukan adalah dengan cara digantung, kaki bagian belakang di atas dan bagian kepala sebelah bawah. Pada ternak ruminansia kecil, kulit tidak melekat erat pada karkas, kecuali bagian rusuk.

\section{Pengambilan data setelah disembelih}

Setelah disembelih dilakukan pengambilan data berat karkas, kulit, kaki, kepala, paru-paru, jantung, hati dan terakhir saluran pencernaan untuk ditimbang.

Karkas adalah hasil pemotongan hewan setelah dikurangi kepala, kedua kaki depan dari carpus kebawah dan kedua kaki belakang dari tarsus kebawah, kulit, darah dan organ-organ dalam (Soeparno, 1994). Nonkarkas adalah hati, kulit, kaki, kepala, paru-paru, jantung dan saluran pencernaan (Soeparno, 1994).

Produksi domba dan kambing dihitung secara rata-rata dari berat potong 1 dan 2 . Produksi domba dan kambing $(\mathrm{kg})$ didapat dengan menjumlahkan karkas dan nonkarkas yang sudah disetarakan dalam nilai (kg) karkas, dengan rumus :
Produksi domba dan kambing $(\mathrm{kg})=$

Berat karkas $(\mathrm{kg})+\underline{\text { Total nilai nonkarkas }(\mathrm{Rp})}$

Harga karkas $(\mathrm{Rp} / \mathrm{kg})$

\section{Analisis data}

Data tentang persentase karkas dan nonkarkas domba dan kambing dianalisis menggunakan Independent-Sample T test. Uji pola faktorial digunakan untuk mengetahui perbedaan antara jenis ternak dan kelompok berat hidup mana yang paling baik untuk produksi per ekor domba dan kambing.

Analisis model regresi berganda digunakan untuk mengetahui pengaruh harga beli, berat potong dan jenis ternak terhadap produksi domba dan kambing, dengan rumus sebagai berikut :

$$
\begin{array}{lll}
\mathrm{Y}_{\mathrm{pr}} & = & \beta_{0}+\beta_{1} \mathrm{X}_{1}+\beta_{2} \mathrm{X}_{2}+\beta_{3} \mathrm{D}+\mu \\
\mathrm{Y}_{\mathrm{pr}} & = & \text { produksi (kg setara karkas/ } \\
& \text { ekor) } \\
\beta_{0} & = & \text { intersept } \\
\beta_{1, \ldots, \beta_{3}}= & \text { koefisien regresi } \\
\mathrm{X}_{1} & = & \text { harga beli (Rp/ekor) } \\
\mathrm{X}_{2} & = & \text { berat potong (kg/ekor) } \\
\mathrm{D} & = & \text { dummy jenis ternak } \\
& & \text { Kambing }=1 \\
& & \text { Domba }=0 \\
\mu & = & \text { stochastic disturbance term }
\end{array}
$$

\section{Uji asumsi klasik}

Beberapa penyimpangan yang sering muncul pada penggunaan metode OLS menyebabkan model menjadi tidak baik. Bentuk deteksi penyimpangan menggunakan asumsi klasik, yaitu:

Multikolinearitas. Multikolinearitas adalah adanya suatu hubungan linear yang sempurna di antara variabel-variabel bebas dalam model regresi. Multikolinearitas dapat dideteksi jika $\mathrm{R}^{2}$ cukup tinggi dan jika koefisien korelasi sederhana juga tinggi $(>0,7)$, tetapi tidak satupun atau sedikit sekali koefisien regresi parsial yang signifikan secara individu (Firdaus, 2004).

Heteroskedastisitas. Varian variabel gangguan yang tidak konstan. Heteroskedastisitas akan sering ditemui dalam data cross section, dan jarang ditemui pada data time series. Hal ini karena ketika menganalisis perilaku data yang sama dari waktu-waktu fluktuasinya akan relatif stabil. Deteksi adanya heteroskedastisitas dapat diketahui dengan menggunakan metode white yaitu dengan melihat nilai probabilitas pada $O b s^{*} R$-squared. Jika nilai tidak signifikan pada $\mathrm{P}<0,05$ maka tidak terbukti adanya heteroskedastisitas (Widarjono, 2007).

Autokorelasi. Autokorelasi merupakan gangguan pada fungsi regresi yang berupa korelasi diantara faktor gangguan. Pada penelitian dengan menggunakan data runtut waktu (time series data) 
kemungkinan adanya autokorelasi lebih besar dari pada penelitian menggunakan data seksi silang (cross section data) (Firdaus, 2004). Ada tidaknya autokorelasi tercapai bila nilai $\mathrm{Obs}^{*} \mathrm{R}$-squared tidak signifikan pada $\mathrm{P}<0,05$ (Widarjono, 2007).

Koefisien determinasi $\left(\mathbf{R}^{2}\right)$. Koefisien determinasi merupakan proporsi variabel dependen yang diterangkan oleh pengaruh linear dari variabel independen. Nilai koefisien determinasi terletak antara nol dan satu. Makin kecil nilai $\mathrm{R}^{2}$ maka makin tidak tepat garis regresi tersebut untuk mewakili data hasil observasi dan model yang digunakan juga kurang tepat.

Uji F. Tujuan menggunakan uji $F$ adalah untuk mengetahui pengaruh semua variabel dependen secara bersama-sama terhadap variabel independen yang dipakai dalam model pengujian hipotesis, maka $\mathrm{F}$ hitung dibandingkan dengan $\mathrm{F}$ tabel pada derajat bebas tertentu.

Uji t. Uji t digunakan untuk mengetahui apakah masing-masing variabel bebas yang diduga berpengaruh nyata terhadap variabel tidak bebas.

\section{Hasil dan Pembahasan}

\section{Kondisi ternak}

Kondisi domba dan kambing yang dipotong di RPH Mentik Bantul sebagian besar berjenis kelamin betina sedangkan untuk ternak jantan hanya dipotong saat ada permintaan khusus dari konsumen seperti aqiqah dan lain-lain. Kondisi ternak yang di ambil dalam penelitian ini adalah kondisi sedang karena setelah dilakukan pengambilan sampel, sebagian besar ternak yang dipotong dalam kondisi sedang. Setiap hari RPH Mentik rata-rata memotong domba dan kambing sebanyak 4 ekor.

\section{Persentase produksi seluruh berat potong}

Dari hasil penelitian didapatkan persentase produksi dari seluruh kelompok berat hidup seperti pada Tabel 1 .

Rata-rata presentase karkas, kulit, kaki, kepala, jantung, hati, paru-paru, saluran pencernaan domba ekor tipis berturut-turut adalah 43,20\%, $10,06 \%, 3,21 \%, 8,17 \%, 0,53 \%, 2,48 \%, 1,74 \%$, 9,49\%. Menurut Muyasaroh (2007), persentase karkas $41,7 \%$; kepala 7,57\%; kulit 10,03\%; kaki $3,05 \%$; jantung $0,64 \%$; hati $2,18 \%$; paru-paru $1,78 \%$ dan saluran pencernaan $8,76 \%$ pada domba lokal betina.

Rata-rata presentase karkas, kulit, kaki, kepala, jantung, hati, paru-paru, saluran pencernaan kambing bligon berturut-turut adalah 45,56\%, $8,04 \%, 3,46 \%, 8,64 \%, \quad 0,61 \%, 2,57 \%, \quad 1,50 \%$, $8,86 \%$. Menurut Koyuncu et al. (2006), persentase kepala $7,83 \%$; kulit $8,57 \%$; jantung $0,67 \%$; hati $2,69 \%$; dan paru-paru $1,67 \%$ pada kambing. Menurut Suparyanto (2002) persentase karkas $53, \%$; jantung $0,91 \%$; hati $3,59 \%$; dan saluran pencernaan $10 \%$ pada kambing.

Umur domba dan kambing yang di potong di RPH seperti tersaji pada Tabel 2.

Domba dan kambing yang dipotong sebagian besar berumur 1-2 tahun $\left(\mathrm{Id}_{1}-\mathrm{I}_{1}\right)$. Sebagian besar

Tabel 1. Rata-rata persentase produksi seluruh kelompok berat potong (\%) (averages of production percentage of all slaughter weight groups (\%))

\begin{tabular}{lcc}
\hline \hline \multicolumn{1}{c}{ Produksi (production) } & $\begin{array}{c}\text { Domba ekor tipis (thin tailed sheep) } \\
\mathrm{n}=60\end{array}$ & $\begin{array}{c}\text { Kambing Bligon (Bligon goat) } \\
\mathrm{n}=60\end{array}$ \\
\hline Karkas (carcass) & 43,20 & 45,56 \\
Kulit (hide) & 10,06 & 8,04 \\
Kaki (leg) & 3,21 & 3,46 \\
Kepala (head) & 8,17 & 8,64 \\
Jantung (heart) & 0,53 & 0,61 \\
Hati (liver) & 2,48 & 2,57 \\
Paru-paru (lung) & 1,74 & 1,50 \\
Saluran Pencernaan (gastrointestinal) & 9,49 & 8,86 \\
\hline
\end{tabular}

Tabel 2. Umur domba dan kambing yang dipotong di RPH berdasarkan atas berat potong (ages of sheep and goat slaughtered in slaughter house based on slaughter weight)

\begin{tabular}{lcccc}
\hline \hline \multirow{2}{*}{ Bangsa (species) } & Berat potong & \multicolumn{2}{c}{ Persentase umur (\%) (age percentage (\%)) } \\
\cline { 3 - 5 } & (slaughter weight) & $<1$ tahun (year) & $1-2$ tahun (year) & $2-3$ tahun (year) \\
\hline Domba ekor tipis & $10-14,99 \mathrm{~kg}$ & 40 & 56,67 & 3,34 \\
(thin tailed sheep) & $15-20 \mathrm{~kg}$ & 40 & 46,67 & 13,34 \\
\hline Kambing Bligon & $10-14,99 \mathrm{~kg}$ & 33,34 & 56,67 & 10 \\
(bligon goat) & $15-20 \mathrm{~kg}$ & 20 & 46,67 & 33,34 \\
\hline
\end{tabular}


Tabel 3. Persentase karkas, kulit, kaki, kepala, jantung, hati, paru-paru dan saluran pencernaan domba dan kambing betina (\%) (carcass, skin, leg, head, heart, liver, lung and gastrointestinal percentages of sheep and goat (\%))

\begin{tabular}{|c|c|c|c|c|}
\hline \multirow{2}{*}{$\begin{array}{l}\text { Jenis ternak } \\
\text { (species) }\end{array}$} & \multirow[b]{2}{*}{ Produksi (production) } & \multicolumn{3}{|c|}{ Berat potong (slaughter weight) } \\
\hline & & $10-14,99 \mathrm{~kg}$ & $15-20 \mathrm{~kg}$ & $\begin{array}{c}\text { Signifikansi } \\
\text { (significancy) }^{1}\end{array}$ \\
\hline \multirow{8}{*}{$\begin{array}{l}\text { Domba ekor } \\
\text { tipis } \\
\text { (thin tailed } \\
\text { sheep) }\end{array}$} & Karkas (carcass) & $45,85 \pm 7,67$ & $42,48+4,97$ & $*$ \\
\hline & Kulit (hide) & $10,33 \pm 2,14$ & $9,77 \pm 2,25$ & $\mathrm{~ns}$ \\
\hline & Kaki (leg) & $3,43 \pm 0,42$ & $2,98 \pm 0,31$ & $* *$ \\
\hline & Kepala (head) & $8,61 \pm 0,95$ & $7,73 \pm 1,19$ & $*$ \\
\hline & Jantung (heart) & $0,54 \pm 0,11$ & $0,52 \pm 0,94$ & * \\
\hline & Hati (liver) & $2,63 \pm 0,53$ & $2,33 \pm 0,41$ & ns \\
\hline & Paru-paru (lung) & $1,76 \pm 0,29$ & $1,70 \pm 0,24$ & * \\
\hline & Saluran Pencernaan (gastrointestinal truct) & $10,10 \pm 1,77$ & $8,87 \pm 1,45$ & $*$ \\
\hline \multirow{8}{*}{$\begin{array}{l}\text { Kambing } \\
\text { Bligon } \\
\text { (Bligon goat) }\end{array}$} & Karkas (carcass) & $45,00+3,12$ & $46,10+4,89$ & ns \\
\hline & Kulit (hide) & $8,29+1,36$ & $7,79+1,36$ & ns \\
\hline & Kaki (leg) & $3,66+0,33$ & $3,26+0,42$ & $* *$ \\
\hline & Kepala (head) & $9,17+1,46$ & $8,11+0,94$ & $*$ \\
\hline & Jantung (heart) & $0,77+0,83$ & $0,45+0,75$ & $*$ \\
\hline & Hati (liver) & $2,68+0,77$ & $2,44+0,47$ & ns \\
\hline & Paru-paru (lung) & $1,60+0,28$ & $1,39+0,23$ & $*$ \\
\hline & Saluran Pencernaan (gastrointestinal truct) & $9,04+1,78$ & $8,67+1,65$ & $\mathrm{~ns}$ \\
\hline
\end{tabular}

ns: non significant, $* \mathrm{P}<0,05, * * \mathrm{P}<0,01$

umur domba dan kambing yang dipotong adalah domba dan kambing dengan umur muda, karena tujuan pemotongan domba dan kambing untuk konsumsi daging olahan seperti sate, gule, tongseng, maka pemotongan domba dan kambing banyak dilakukan pada domba dan kambing umur muda yang banyak disukai oleh konsumen karena dagingnya lebih empuk.

\section{Persentase karkas dan nonkarkas}

Hasil analisis persentase karkas, kulit, kaki, kepala, jantung, hati, paru-paru dan saluran pencernaan dari tiap-tiap kelompok berat potong domba dan kambing betina tersaji pada Tabel 3 .

\section{Persentase karkas}

Hasil analisis dengan uji Independent Sample $T$ Test (Tabel 3) menunjukkan bahwa berat potong domba betina memberikan pengaruh yang berbeda $(\mathrm{P}<0,05)$ terhadap persentase karkas. Hasil analisis menunjukkan bahwa $\mathrm{BP}_{1}$ memiliki persentase yang paling besar yaitu $45,85 \pm 7,67 \%$ diikuti $\mathrm{BP}_{2}$ sebesar $42,48 \pm 4,97 \%$. Hal ini sesuai dengan yang dikemukakan oleh Soeparno (1994) bahwa, komposisi tubuh berhubungan erat dengan berat tubuh yang mempengaruhi komposisi karkas. Awal pertumbuhan ternak dimulai dari tulang, otot (daging) dan terakhir lemak (Soeparno, 1994).

Hasil analisis menunjukkan bahwa berat potong kambing betina tidak memberikan pengaruh yang berbeda terhadap persentase karkas. Hasil analisis menunjukkan bahwa $\mathrm{BP}_{1}$ memiliki persentase sebesar $45,00 \pm 3,12 \%$ dan $\mathrm{BP}_{2}$ sebesar $46,10+4,89 \%$.

Hasil penelitian antara domba dengan kambing berbeda, ini dikarenakan deposisi lemak yang terjadi pada domba. Selain dipengaruhi oleh nilai nutrisi pakan ternak, perlemakan tubuh ternak juga ditentukan oleh waktu atau berat pemotongan ternak. Berat potong yang semakin meningkat manghasilkan karkas yang semakin meningkat pula (Soeparno, 1994). Dengan semakin meningkatnya berat karkas, maka persentase lemak meningkat (Herman, 1993). Deposisi lemak merupakan fungsi linier dengan waktu dan umur ternak (Soeparno, 1994).

\section{Persentase kulit}

Hasil analisis menunjukkan bahwa berat potong domba betina tidak memberikan pengaruh yang berbeda terhadap persentase kulit. Hasil penelitian sebelumnya dilakukan oleh Suilianto (2004) yang mendapatkan bahwa persentase kulit domba betina lokal kurang dari satu tahun adalah $8,35 \pm 1,53 \%$ dan umur lebih dari satu tahun sebesar $8,42 \pm 1,67 \%$ (Likadja, 2009).

Hasil analisis menunjukkan bahwa berat potong kambing betina tidak memberikan pengaruh yang berbeda terhadap persentase kulit. Menurut Koyuncu etal. (2006), persentase kulit 8,57\%, 
sedangkan Soeparno et al. (2001) menyatakan, persentase kulit sekitar 8-12\%.

\section{Persentase kaki}

Hasil analisis menunjukkan bahwa berat potong domba betina memberikan pengaruh yang berbeda $(\mathrm{P}<0,01)$ terhadap persentase kaki. Berat Potong $1 \quad\left(\mathrm{BP}_{1}\right)$ memberikan persentase yang terbesar yaitu 3,43\% dan $\mathrm{BP}_{2}$ sebesar $2,98 \%$. $\mathrm{BP}_{1}$ memberikan persentase terbesar membuktikan bahwa kaki sebagian besar tersusun oleh tulang (Soeparno, 1994). Menurut Herman (2005), persentase kaki domba Priangan adalah 2,75 dan Domba ekor gemuk adalah 2,77.

Hasil analisis menunjukkan bahwa berat potong kambing betina memberikan pengaruh yang berbeda $(\mathrm{P}<0,01)$ terhadap persentase kaki. Berat Potong $1\left(\mathrm{BP}_{1}\right)$ memberikan persentase yang terbesar yaitu $3,66 \%$ dan $\mathrm{BP}_{2}$ sebesar $3,26 \%$. Persentase kaki kambing umur 8 bulan adalah $2,42 \%$ dan umur 15 bulan $2,05 \%$.

\section{Persentase kepala}

Hasil analisis menunjukkan bahwa berat potong domba betina memberikan pengaruh yang berbeda $(\mathrm{P}<0,05)$ terhadap persentase kepala. Berat Potong $1\left(\mathrm{BP}_{1}\right)$ memberikan persentase terbesar dibanding $\mathrm{BP}_{2}$. Menurut Muyasaroh (2007), persentase kepala $7,57 \%$. Berat potong kambing betina memberikan pengaruh yang berbeda $(\mathrm{P}<0,05)$ terhadap persentase kepala. Berat Potong 1 $\left(\mathrm{BP}_{1}\right)$ memberikan persentase terbesar. Menurut Koyuncu et al. (2006), persentase kepala adalah $7,83 \%$.

Berat potong yang tinggi menyebabkan proporsi kepala semakin kecil, penurunan proporsi kepala disebabkan karena organ kepala merupakan organ tubuh yang masak dini, sehingga proporsinya cenderung mengalami penurunan ketika mencapai dewasa tubuh (Black, 1983, cit Setiyono, 1987).

\section{Persentase jantung}

Hasil analisis menunjukkan bahwa berat potong domba betina memberikan pengaruh yang berbeda $(\mathrm{P}<0,05)$ terhadap persentase jantung. Hal ini dikarenakan pertumbuhan organ-organ seperti jantung, hati, dan paru-paru akan berkembang sesuai dengan berat tubuh dan akan menurun setelah mencapai dewasa tubuh.

Hasil analisis menunjukkan bahwa berat potong kambing betina memberikan pengaruh yang berbeda $(\mathrm{P}<0,05)$ terhadap persentase jantung. Berat Potong $1\left(\mathrm{BP}_{1}\right)$ memberikan persentase terbesar pada jantung. Menurut Koyuncu et al. (2006) persentase jantung $0,67 \%$. Menurut Suparyanto (2002) persentase jantung $0,91 \%$ dengan persentase karkas $53,90 \%$.

\section{Persentase hati}

Hasil analisis menunjukkan bahwa berat potong domba dan kambing betina tidak memberikan pengaruh yang berbeda terhadap persentase hati pada setiap kelompok berat potong. Menurut Koyuncu et al. (2006), persentase hati 2,69\%, sedangkan menurut Suparyanto (2002), persentase hati $3,59 \%$.

\section{Persentase paru-paru}

Hasil analisis dalam penelitian ini menunjukkan bahwa berat potong domba dan kambing betina memberikan pengaruh yang berbeda $(\mathrm{P}<0,05)$ terhadap persentase paru-paru. Berat Potong $1\left(\mathrm{BP}_{1}\right)$ memberikan persentase terbesar dibanding $\mathrm{BP}_{2}$. Menurut Muyasaroh (2007), persentase hati 1,78\%, Menurut Koyuncu et al. (2006) persentase paruparu 1,67\%. Menurut Soeparno (1994), pertumbuhan paru-paru hampir sama dengan laju pertumbuhan tubuh, paru-paru berkembang mulai dari lahir dan menurun pada saat mencapai kedewasaan. Persentase berat hati dan paru-paru menurun pada umur yang lebih tua, terjadi karena kecenderungan pertumbuhan hati dan paru-paru yang masuk pada golongan masak dini (Likadja, 2009).

\section{Persentase saluran pencernaan}

Hasil analisis menunjukkan bahwa berat potong pada domba betina memberikan pengaruh yang berbeda $(\mathrm{P}<0,05)$ terhadap persentase saluran pencernaan, sedangkan pada kambing betina berat potong tidak berpengaruh terhadap persentase saluran pencernaan. Hal ini dikarenakan organ yang berhubungan dengan digesti dan metabolisme menunjukkan pertambahan berat yang besar sesuai dengan status nutrisional dan fisiologis ternak. Kadar laju pertumbuhan relatif beberapa komponen nonkarkas hampir sama dengan laju pertumbuhan tubuh (Soeparno, 1994). Menurut Suparyanto (2002), persentase saluran pencernaan terhadap berat hidup adalah $10 \%$. Hasil penelitian antar domba dengan kambing berbeda, ini dikarenakan deposisi lemak pada saluran pencernaan yang terdapat pada domba. Deposisi lemak pada domba yang berumur muda terjadi di sekitar jeroan dan ginjal. Lemak omental adalah lemak yang menyelimuti retikulum, rumen, omasum dan abomasum (Soeparno,1994).

\section{Produksi domba dan kambing}

Produksi domba dan kambing dari berat potong ternak seperti tersaji pada Tabel 4. Hasil analisis dengan uji faktorial menunjukkan bahwa berat potong dan jenis ternak memberikan pengaruh yang nyata $(\mathrm{P}<0,05)$ terhadap produksi domba dan 
Tabel 4. Rata-rata produksi domba dan kambing betina (kg setara karkas/ekor) (averages of sheep and goat's production)

\begin{tabular}{|c|c|c|c|}
\hline \multirow{2}{*}{$\begin{array}{c}\text { Berat potong } \\
\text { (slaughter weight) }\end{array}$} & \multicolumn{2}{|c|}{ Jenis ternak (species) } & \multirow{2}{*}{$\begin{array}{c}\text { Rerata } \\
\text { (average) }\end{array}$} \\
\hline & Domba ekor tipis (thin tailed sheep) & Kambing Bligon (Bligon goat) & \\
\hline $10-14,99 \mathrm{~kg}$ & 7,68 & 7,61 & $7,65^{\AA}$ \\
\hline $15-20 \mathrm{~kg}$ & 7,68 & 9,83 & $8,76^{\mathrm{B}}$ \\
\hline Rerata (average) & $7,68^{\mathrm{a}}$ & $8,72^{\mathrm{b}}$ & \\
\hline
\end{tabular}

a,b Superskrip yang berbeda pada baris yang sama menunjukkan perbedaan yang nyata $(\mathrm{P}<0,05)($ different superscripts at the same row indicate significant differences $(P<0.05))$

${ }_{\mathrm{A}, \mathrm{B}}$ Superskrip yang berbeda pada kolom yang sama menunjukkan perbedaan yang nyata $(\mathrm{P}<0,05)($ different superscripts at the same column indicate significant differences $(P<0.05))$

Tabel 5. Harga bagian-bagian tubuh domba dan kambing pada saat penelitian (price of sheep and goats component at the time of study)

\begin{tabular}{lcc}
\hline \hline \multicolumn{1}{c}{ Bagian-bagian tubuh (body parts) } & Jumlah (total) & Harga (Rp.) (price (Rp.)) \\
\hline Karkas+hati+jantung (per kg) (carccas + heart+liver (per kg)) & 1 & $50.000,00$ \\
Kulit per lembar (hide per piece) & 1 & $25.000,00$ \\
Kepala per lembar (head per piece) & 1 & $25.000,00$ \\
Kaki per lembar (leg per piece) & 1 & $5.000,00$ \\
Saluran pencernaan dan paru-paru (per kg) (gastrointestinal and & & $12.000,00$ \\
lung (per $\mathrm{kg})$ ) & & \\
\hline
\end{tabular}

Tabel 6. Rata-rata penerimaan domba dan kambing lokal betina (averages of income from female sheep and goat)

\begin{tabular}{llcc}
\hline \hline \multirow{2}{*}{$\begin{array}{c}\text { Jenis ternak } \\
\text { (species) }\end{array}$} & \multicolumn{1}{c}{ Penerimaan (income) } & \multicolumn{2}{c}{ Berat potong (slaughter weight) } \\
\cline { 3 - 4 } Domba ekor tipis & Karkas, hati, jantung (carcass, liver, heart) & $10-14,99 \mathrm{~kg}(\mathrm{Rp})$. & $15-20 \mathrm{~kg}(\mathrm{Rp})$. \\
(thin tailed & Nonkarkas (noncarcass) & $71.070,33$ & $386.593,33$ \\
sheep) & Penerimaan (income) & $384.116,33$ & $73.124,00$ \\
\hline Kambing Bligon & Karkas, hati, jantung (carcass, liver, heart) & $311.349,33$ & $459.717,33$ \\
(Bligon goat) & Nonkarkas (noncarcass) & $69.004,00$ & $72.930,83$ \\
& Penerimaan (income) & $380.353,33$ & $491.734,83$ \\
\hline
\end{tabular}

kambing. Berat potong II memberikan produksi terbesar di banding berat potong I pada domba dan kambing. Produksi kambing lebih baik dari pada produksi domba. Kambing dengan berat potong $15-$ $20 \mathrm{~kg}$ menghasilkan nilai produksi yang paling tinggi yaitu sebesar $9,83 \mathrm{~kg}$.

Berat potong ditentukan oleh berat hidup dan kondisi eksterior ternak. Berat potong akan berpengaruh terhadap persentase karkas dan nonkarkas. Razi (2004) menyatakan bahwa perbedaan berat potong akan sangat berpengaruh terhadap persentase karkas yang dihasilkannya karena setiap kenaikan berat potong akan diikuti oleh kenaikan berat karkas.

\section{Penerimaan}

Penerimaan jagal atau nilai produksi domba dan kambing dapat dibedakan menjadi dua bagian penerimaan yaitu penerimaan dari penjualan hasil utama berupa karkas dan penerimaan dari penjualan sampingan berupa nonkarkas. Komponen nonkarkas di RPH Kresen tidak semuanya dihargai ber- dasarkan beratnya, namun untuk kepala, kulit, dan kaki dihargai berdasarkan satuan dan tidak dibedakan besar kecilnya seperti yang tersaji pada Tabel 5 .

Penerimaan dari penjualan karkas dan nonkarkas tersaji pada Tabel 6 . Tabel 6 menunjukkan bahwa penerimaan utama jagal berasal dari karkas, sedangkan nonkarkas hanya merupakan hasil sampingan. Karkas merupakan komponen utama dari berat potong yang memiliki nilai ekonomis yang lebih tinggi dibandingkan nonkarkas. Penerimaan tertinggi terdapat pada kambing dengan berat $15-20 \mathrm{~kg}$ yaitu sebesar Rp. 491.734,83. Hal ini menunjukkan bahwa penerimaan jagal meningkat dengan peningkatan berat potong domba dan kambing betina lokal.

\section{Gross margin}

Gross margin adalah total penerimaan dikurangi biaya variabel (variable cost). Gross margin jagal tersaji pada Tabel 7. 
Tabel 7. Biaya variabel jagal (variable cost of the butchers)

\begin{tabular}{lc}
\hline \hline Biaya variabel (variable cost) & $\begin{array}{c}\text { Nilai (Rp./ekor) } \\
(\text { value } \\
(\text { Rp./head) })\end{array}$ \\
\hline Tenaga pemotongan (labor) & $7.000,00$ \\
Retribusi RPH (retribution) & $2.000,00$ \\
Biaya angkut (transportation) & $5.000,00$ \\
Tanda ternak (labeling) & $1.000,00$ \\
Pakan+masak+kayu & $2.500,00$ \\
$($ feed + cook + wood $)$ & \\
\hline
\end{tabular}

Berdasarkan Tabel 8 diketahui bahwa gross margin jagal tertinggi terdapat pada kambing dengan berat potong $15-20 \mathrm{~kg}$ yaitu sebesar Rp. 104.901,5/ekor. Hal ini menunjukkan bahwa gross margin jagal meningkat dengan peningkatan berat potong domba dan kambing betina lokal. Ternak yang dipotong pada berat potong II sebagian besar berumur 1-2 tahun. Pemotongan pada usia muda (11,5 tahun) tersebut dikarenakan konsumen lebih menyukai daging kambing muda dan ditinjau dari segi ekonomis lebih menguntungkan bagi peternak yang juga bergerak dalam usaha pemotongan karena pada usia tersebut persentase karkasnya tinggi dan dapat dikonversikan secara optimal terhadap pendapatan peternak (Kurniawan, 2009).

Faktor-faktor yang mempengaruhi produksi dan gross margin jagal domba dan kambing lokal betina

\section{Faktor-faktor yang mempengaruhi produksi domba dan kambing}

Hasil analisis faktor-faktor yang berpengaruh terhadap produksi jagal domba dan kambing lokal betina tersaji pada Tabel 9 .

Tabel 9 menunjukkan produksi domba dan kambing lokal betina dipengaruhi harga beli, berat potong dan bangsa dengan $\mathrm{R}^{2}=0,718$ artinya besarnya produksi domba dan kambing ditentukan oleh harga beli, berat potong dan jenis ternak sebesar $71,8 \%$ dan sisanya sebesar $28,2 \%$ dipengaruhi oleh faktor lain yang tidak dimasukkan ke dalam pendugaan ini. Secara parsial berat potong dan dummy jenis ternak berturut-turut berpengaruh terhadap produksi domba dengan tingkat signifikansi $(\mathrm{P}<0,01)$ dan $\quad(\mathrm{P}<0,05)$. Hal ini

Tabel 8. Rata- rata gross margin jagal domba dan kambing lokal betina (Rp.) (averages of slaughter's gross margin of local female sheep and goat (Rp.))

\begin{tabular}{clcc}
\hline \hline $\begin{array}{c}\text { Jenis ternak } \\
\text { (species) }\end{array}$ & \multicolumn{1}{c}{ Uraian (description) } & \multicolumn{2}{c}{ Berat potong (slaughter weight) } \\
\cline { 3 - 4 } & \multicolumn{1}{c}{$10-14,99 \mathrm{~kg}(\mathrm{Rp})}$. & $15-20 \mathrm{~kg}(\mathrm{Rp})$. \\
\hline Domba (sheep) & Penerimaan karkas-non karkas (income from & $384.116,33$ & $459.717,33$ \\
& carcass-noncarcass) & & \\
& Variabel cost & $331.500,00$ & $377.333,30$ \\
& Gross margin & $52.616,33$ & $82.384,00$ \\
\hline Kambing (goat) & Penerimaan karkas-non karkas & $380.353,33$ & $491.734,83$ \\
& (income from carcass-noncarcass) & $346.666,70$ & $386.833,30$ \\
& Variabel cost & $33.686,67$ & $104.901,50$ \\
\hline
\end{tabular}

Tabel 9. Hasil analisis regresi produksi domba dan kambing pada jagal di Kresen Bantul (results of regresion analysis of sheep and goat's production at butchers in Kresen Bantul)

\begin{tabular}{lcccc}
\hline \hline \multicolumn{1}{c}{ Variabel (variable) } & $\begin{array}{c}\text { Koefisien regresi } \\
\text { (regresion coefisien) }\end{array}$ & SE & t-hitung & Sig. \\
\hline Konstanta (constanta) & 1,672532 & 0.451108 & 3,707606 & 0,0003 \\
Harga beli $\left(\mathrm{X}_{1}\right)$ (purchasing & $2,63 \mathrm{E}-06$ & $1.57 \mathrm{E}-06$ & $1,674938^{\mathrm{ns}}$ & 0,0966 \\
price $\left.\left(X_{1}\right)\right)$ & & & & \\
Berat potong $\left(\mathrm{X}_{2}\right)$ (slaughter & 0,385798 & 0.031323 & $12,31696^{* *}$ & 0,0000 \\
weight $\left.\left(X_{2}\right)\right)$ & 0,335242 & 0.130109 & $2,576623^{*}$ & 0,0112 \\
Dummy & 0,718847 & & & \\
\hline R-squared & 0,711576 & & & \\
Adjusted R-squared & 98,86234 & & & \\
F hitung & 0,000000 & & & \\
Prob (F-stat) & & & \\
** Signifikan pada tingkat kepercayaan $99 \%$ & & & \\
* Signifikan pada tingkat kepercayaan $70 \%$ & & &
\end{tabular}


Tabel 10. Analisis regresi gross margin domba dan kambing pada jagal di Kresen Bantul (gross margin regresion analysis of sheep and goat of butchers in Kresen Bantul)

\begin{tabular}{lcccc}
\hline \hline \multicolumn{1}{c}{ Variabel (variable) } & $\begin{array}{c}\text { Koefisien regresi } \\
\text { (regresion coefisien })\end{array}$ & SE & t-hitung & Sig. \\
\hline Konstanta $($ constanta $)$ & 40857,60 & 20871.75 & 1,957555 & 0,0527 \\
$\begin{array}{l}\text { Berat potong }\left(\mathrm{X}_{1}\right) \\
\left.\text { purchasing price }\left(X_{1}\right)\right)\end{array}$ & 13945,03 & 1403.053 & $9,939061^{* *}$ & 0,0000 \\
Biaya variabel $\left(\mathrm{X}_{2}\right)$ & $-0,505986$ & 0.070360 & $-7,191387^{* *}$ & 0,0000 \\
(slaughter weight $\left.\left(X_{2}\right)\right)$ & & & \\
Dummy & 13908,57 & 5828.078 & $2,386476^{*}$ & 0,0186 \\
\hline R-squared & 0,665888 & & & \\
Adjusted R-squared & 0,652074 & & & \\
F hitung & 33,72760 & & & \\
Prob (F-stat) & 0,000000 & & & \\
\hline ** Signifian par & & &
\end{tabular}

** Signifikan pada tingkat kepercayaan $99 \%$

* Signifikan pada tingkat kepercayaan 95\%

disebabkan harga beli tidak berpengaruh terhadap produksi domba dan kambing. Harga beli ternak dilakukan dengan melihat berat badan ternak secara estimasi atau perkiraan (taksiran atau jogrog). Oleh karena itu sebaiknya dilakukan penimbangan untuk mengetahui berat badan ternak.

Hasil analisis dummy variabel menunjukkan bahwa domba dan kambing mempunyai pengaruh yang berbeda terhadap produksi dengan koefisien $\left(\beta_{3}\right)$ sebesar $0,33 \mathrm{~kg}$; yang berarti produksi kambing lebih tinggi dari domba kira-kira 0,33 kg. Persamaan garis regresi dummy adalah:

$$
\mathrm{Y}=1,67+2.63 \cdot 10^{-6} \mathrm{X}_{1}+0,38 \mathrm{X}_{2}+0,33 \mathrm{D}
$$

Garis regresi dummy disajikan dalam Gambar 1.

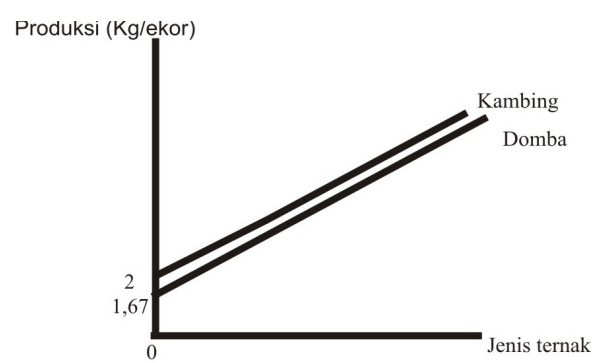

Gambar 1. Garis regresi dummy produksi domba dan kambing (dummy's regresion curve of sheep and goat's production)

\section{Faktor-faktor yang mempengaruhi gross margin jagal}

Hasil analisis faktor-faktor yang berpengaruh terhadap gross margin jagal domba dan kambing lokal betina seperti tersaji pada Tabel 10 . Tabel 10 menunjukkan bahwa gross margin domba dan kambing lokal betina dipengaruhi secara signifikan oleh berat potong $\left(\mathrm{X}_{1}\right)$, biaya produksi $\left(\mathrm{X}_{2}\right)$ dan jenis ternak secara bersama-sama dengan $\mathrm{R}^{2}=$ 0,665 ; artinya besarnya gross margin domba dan kambing ditentukan oleh berat potong, biaya variabel dan jenis ternak sebesar $66,5 \%$ dan $33,5 \%$ oleh faktor lain yang tidak dimasukkan ke dalam pendugaan ini. Secara parsial berat potong $\left(\mathrm{X}_{1}\right)$, biaya variabel $\left(\mathrm{X}_{2}\right)$ dan jenis ternak berturut-turut berpengaruh secara nyata terhadap gross margin domba dan kambing dengan tingkat signifikansi $(\mathrm{P}<0,01)$; $(\mathrm{P}<0,01)$; dan $(\mathrm{P}<0,05)$.

Hasil analisis dummy variabel menunjukkan bahwa domba dan kambing mempunyai pengaruh yang berbeda terhadap gross margin jagal dengan koefisien $\left(\beta_{3}\right)$ sebesar 13908,57; berarti gross margin kambing lebih tinggi kurang lebih $\mathrm{Rp}$. 13908,57/ekor dari domba. Persamaan garis regresi adalah:

$\mathrm{Y}=40857,60+13945,03 \mathrm{X} 1-0,505986 \mathrm{X}_{2}+13908,57 \mathrm{D}$

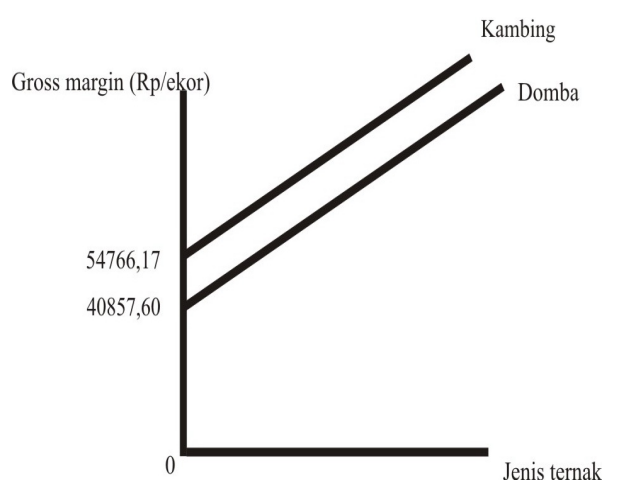

Gambar 2. Garis regresi dummy gross margin domba dan kambing (dummy's regresion curve of sheep and goat gross margin)

\section{Kesimpulan} bahwa :

Dari hasil penelitian ini dapat disimpulkan

1. Kambing Bligon betina dengan berat potong 15-20 kg menghasilkan nilai produksi dan gross margin yang paling tinggi yaitu sebesar 9,83 $\pm 1,11 \mathrm{~kg}$ dan Rp.104.901,50/ekor.

2. Pada domba, persentase karkas, kaki, kepala, jantung, paru-paru dan saluran pencernaan memberikan pengaruh yang berbeda antara 
kelompok $\mathrm{BP}_{1}$ dengan $\mathrm{BP}_{2}$, sedangkan persentase kulit dan hati tidak memberikan pengaruh yang berbeda. Pada kambing, persentase kaki, kepala, jantung dan paru-paru memberikan pengaruh yang berbeda antara kelompok $\mathrm{BP}_{1}$ dengan $\mathrm{BP}_{2}$, sedangkan persentase karkas, kulit, hati dan saluran pencernaan tidak memberikan pengaruh yang berbeda.

3. Harga beli tidak berpengaruh terhadap produksi domba dan kambing lokal betina. Berat potong secara signifikan dan positif berpengaruh terhadap produksi domba dan kambing lokal betina. Terdapat perbedaan produksi pada domba dan kambing yaitu produksi kambing lebih baik dibandingkan dengan produksi domba.

4. Berat potong secara signifikan dan positif berpengaruh terhadap gross margin jagal. Biaya variabel secara signifikan dan negatif berpengaruh terhadap gross margin jagal. Terdapat perbedaan gross margin domba dan kambing yaitu gross margin kambing lebih baik dari pada gross margin domba.

\section{Daftar Pustaka}

Anonimus. 2000. Meat. International Magazine. Volume 10.

Djajanegara, A. dan A. Misniwaty. 2007. Pengembangan Usaha Kambing dalam Konteks Sosial-Budaya Masyarakat. Loka Karya Nasional Kambing Potong. Balai Penelitian Veteriner, Pusat Penelitian dan Pengembangan Peternakan. Bogor.

Firdaus, M. 2004. Ekonometrika Suatu Pendekatan Aplikatif. Bumi Aksara. Jakarta.

Herman, R. 1993. Perbandingan Pertumbuhan, Komposisi Tubuh dan Karkas antara Domba Priangan dan Ekor Gemuk. Disertasi. Program Pasca Sarjana. Institut Pertanian Bogor. Bogor.

Herman, R. 2005. Produksi Karkas dan NonKarkas Domba Priangan dan Ekor Gemuk pada Bobot Potong 17,5 dan $25,0 \mathrm{Kg}$. Media Peternakan, V. 28: 8-12.

Koyuncu, M., S. Duru, S. Kara Uzun, S. Ozis and E. Tuncel. 2006. Effect of Castration on Growth and Carcass Traits in Hair Goat Kids Under a
Semi-intensive System in the South-Marmara Region of Turkey. University of Uludag. Faculty of Agriculture. Department of Animal Science. Turkey.

Kurniawan, R.Y. 2009. Karakteristik Produksi Karkas Kambing Peranakan Ettawa. Available at: http://labpotongfapet-ubnews. blogspot.com. Accession date $21^{\text {th }}$ March 2009.

Likadja, J. C. 2009. Persentase NonKarkas dan Jeroan kambing Kacang pada Umur dan Ketinggian Wilayah Berbeda di Sulawesi Selatan. Buletin Ilmu Peternakan dan Perikanan, 13 (1): 29-35.

Muyasaroh, S. 2007. Pengaruh Umur dan Berat Potong Terhadap Persentase Karkas dan NonKarkas Pada Domba Lokal Betina. Skripsi Fakultas Peternakan, Universitas Gadjah Mada. Yogyakarta.

Razi, F. 2004. Hubungan antara Berat hidup dengan Ukuran Tubuh dan Berat Karkas Pada Domba Ekor Tipis di Tempat Pemotongan Hewan Kentungan Kabupaten Sleman DIY. Skripsi Sarjana Peternakan. Fakultas Peternakan. UGM, Yogyakarta.

Setiyono. 1987. Hubungan Kualitas Fisik Dengan Komposisi Fisik dan Kimia Karkas dan Daging Domba Lokal Jantan yang diberi Pakan dengan Level Energi dan Berat Potong yang Berbeda. Tesis S2. Universitas Gadjah Mada. Yogyakarta.

Soeparno. 1994. Ilmu dan Teknologi Daging. Gadjah Mada University Press. Yogyakarta.

Soeparno, Indratiningsih, S. Triatmojo, Rihastuti. 2001. Dasar Teknologi Hasil Ternak. Jurusan Teknologi Hasil Ternak. Fakultas Peternakan, Universitas Gadjah Mada, Yogyakarta.

Suilianto. 2004. Pengaruh Jenis Kelamin, Umur dan Berat Potong Terhadap Karkas dan Non Karkas Domba Lokal yang disembelih di Rumah Potong Hewan Kota Yogyakarta. Skripsi Sarjana Peternakan, Fakultas Peternakan Universitas Gadjah Mada, Yogyakarta.

Suparyanto, A. 2002. Mengenal Ekspresi dan Karakteristik Gen Callipyge Pada Kambing. Balai Penelitian Ternak. Bogor.

Widarjono, A. 2007. Ekonometri Teori dan Aplikasi. Edisi Kedua. Penerbit. Ekonisia.Yogyakarta. 